\title{
Establishment of Institutions and Empowerment of Dayak Tradition (Study in Murung Raya District)
}

\author{
Saut Romy Situmeang ${ }^{*}$, Setia Budhi, Jamal Uddin
}

Master Program of Government Science, Lambung Mangkurat University, Banjarmasin, Indonesia

DOI: $10.36348 /$ sijlcj.2020.v03i06.002

| Received: 29.05.2020 | Accepted: 05.06.2020 | Published: 12.06.2020

*Corresponding author: Saut Romy Situmeang

\section{Abstract}

This study aims to analyze the institutional formation and empowerment of Dayak Adat in the Murung Raya District area and the supporting and inhibiting factors for the implementation of the Institutional Formation and the empowerment of the Dayak Adat in the Murung Subdistrict area. The research approach uses qualitative research because the research problems studied are holistic, complex, dynamic, and full of meaning. The research method is field research which is a type of research that is oriented towards collecting empirical data in the field. Data collection techniques in this study were carried out by interview, some notes that were found in the field, and available documentation relating to this research. Data analysis is carried out using several key steps namely reducing data and presenting data to process the data that has been reduced in the form of a brief description that illustrates the findings of the study. The results of research on empowerment and preservation and development of Customs, customs in the community and Customary Institutions in the Regions are supporting the smooth running of the Government, the continuity of development and enhancing national resilience as well as to encourage efforts to prosper local citizens and encourage, support and increase community participation for fluency Government, Implementation of development and community development in the Region.

Keywords: Institutional, Empowerment, and Dayak Tradition.

Copyright @ 2020: This is an open-access article distributed under the terms of the Creative Commons Attribution license which permits unrestricted use, distribution, and reproduction in any medium for non-commercial use (NonCommercial, or CC-BY-NC) provided the original author and source are credited.

\section{Preliminary}

A new era of regional autonomy in Indonesia has been established ConstitutionNumber 23 of 2014 replaces Law Number 32 of 2004 concerning regional government entering a new round of regional government system [1]. Many positive aspects are expected to strengthen the implementation of regional autonomy, one of the new changes is in the authority of the administration of government affairs at the central and regional levels. The spirit of Law 23 of 2014 concerning regional government is to redefine Regional Autonomy. Conceptually the granting of the broadest possible autonomy to the Regions is directed to accelerate the realization of people's welfare through service improvement, empowerment, and community participation [2].

Broad autonomy, in the strategic environment of globalization, the Region is expected to be able to increase competitiveness by paying attention to the principles of democracy, equity, justice, privileges, and specificities as well as the potential and diversity of Regions in the system of the Unitary State of the Republic of Indonesia [3]. Regional Autonomy in the context of state law is implemented based on the principle of a unitary state. In a unitary state, sovereignty is only in the state government or national government and there is no sovereignty in the Region. Therefore, the area of any autonomy granted to the Region, the final responsibility for the administration of the Regional Government will remain in the hands of the Central Government.

In the local government, the empowerment of community and village affairs as basic non-service compulsory affairs is realized informing the Office of Community and Village Empowerment or other designations before the adjustment of the law in the form of Community Empowerment and Village Government. There are adjustments to the structure and workload organization. For this reason, with the formation of the PMD Office, one of the main tasks which are the business of the regional government is the matter of community empowerment. Thus, the government apparatus in the region is always demanded to take a large role in empowering the people in its territory [4]. 
Community empowerment as an effort to develop the community through the creation of conditions that enable the community to be able to independently develop themselves and their environment through the provision of resources, opportunities for decision making, and improvement of community knowledge and skills. The development of government in translating regional autonomy through Law 23 of 2014 became an important moment in the development of the Implementation of Community Empowerment Affairs in Local Government.

In achieving optimal Regional Development goals, it is necessary to pay attention to the balance of social, cultural, and environmental aspects. Through policies made by the local government for the community, empowerment can strengthen the development goals of the community to become more capable and prosperous. The increase in people's purchasing power is one of the signs of an increase in people's welfare, followed by an increase in consumption, then an increase in community income will encourage increased production which in turn makes employment opportunities open. One focus of activity development social welfare is in the field of community empowerment which is also one of the functions of government apart from the function of development and service functions [5].

Decentralization policy brings social distance between policymakers and the public who feel the impact of the policy making the policy will feel the direct impact of the policy it has taken. Therefore, it is hoped that the policies taken will be more in line with the actual reality and more space for community participation.

Goals and Targets formulated by a Regional Government to reach the Regional Mission Vision then needs to be emphasized with the efforts of the Regional Development strategy for the next 5 years to achieve the regional mission. The said development strategy needs to be supported by regional policies [6]. Affairs of community and village empowerment as mandatory and not affairs service basic giving consequences responsible Implementation of more community empowerment rest onto the local government community empowerment must be one of the development priorities held by the local government as an effort to approach services to the community. This also causes the regional government in allocating the budget in its APBD must prioritize funding for the implementation of Community and Village Empowerment. To further spur efforts on regional empowerment through its implementation, it must be handled by the Regional Apparatus that is authorized for this matter. Therefore, the Murung Raya Regency government established and established the Regional Apparatus of the Community and Village Empowerment Agency as the regional organizational apparatus in the Murung Raya Regency following the stipulation of the Murung Raya Regent Regulation number 17 of 2016, a follow-up of Government Regulation Number 18 of 2016.

The Murung Raya Regency Community and Village Empowerment Office are one of the regional apparatus organizations that have the task of carrying out some of the governmental tasks in the field of Community and Village Empowerment as well as carrying out the tasks of preparing and implementing specific regional policies in Community and Village Empowerment. Device Organizationarea These tasks are assigned to each of them, including the Village and Village Administration Sector, Village Development Institutions and Services Division Social Basic, Community Empowerment in Natural Resources and Appropriate Technology, Community Economic Business Sector. The Office of Community and Village Empowerment of Murung Raya Regency in that relationship has the responsibility to empower the potential of the community in the community empowerment sector so that the community can be independent in developing their regions which in turn will increase the degree of community life to create a prosperous society. This article aims to describe the implementation, the factors that support and hinder the successful implementation of the program. The implementation process is not following the applicable provisions based on the Indigenous community empowerment policy at the District Office of Murung Raya.

\section{RESEARCH METHODS}

The research approach used is descriptive qualitative which is to explain the phenomenon under study. According to Bogdan and Taylor [7], a qualitative research approach is a research procedure that produces descriptive data [8]. This analysis emphasizes the understanding of the problems in social life based on real conditions or natural settings that are holistic, complex, and detailed that are explained in detail or through the disclosure of written or oral words from people, certain events in detail and depth and observable behavior [9].

Data collection techniques passed by three steps by researchers in data collection, namely; 1) Observation is used to see and explore the implementation of Community Empowerment in the community and village empowerment offices especially in concentration on Community Empowerment Activities; 2) Interviews are conducted as a process of collecting data by the question and answer and face to face by researchers and respondents using the interview guide (interview guidelines); and 3) Done by studying and studying or documents relating to the problem under study [9]. 
Qualitative data analysis is carried out simultaneously with the data collection process taking place, meaning that these activities are carried out also during and after data collection [10]. 1) Data Reduction; Data obtained at the research location (field data) is outlined in a detailed or detailed description or report. Reports from the field will be reduced, summarized, selected main points, focused on important matters according to research subjects; 2) Presentation of Data in the form of narrative text; 3) Drawing conclusions based on data that has been presented and interpreted. Data validity (validity) is carried out by employing Data Triangulation and Theory Triangulation.

\section{RESULTS AND DISCUSSION}

Kedamangan is a Dayak Customary Institution that has customary territories, customary community unity, and customary law in the Central Kalimantan Province which consists of a collection of several villages, villages, districts, districts, cities in their operations seeking their budgetary sources or other legitimate budgetary sources and assistance from Provincial / Regency / City Regional Revenue and Expenditure Budget. The preservation of Dayak customs is a joint responsibility of the Provincial, Regency / City, and Community Governments so that the Provincial Government and Regency / City Governments need to jointly assist in the smooth operation of the Institutional Functionary Institution.

The recognized Dayak Traditional Institution which has existed since the beginning of the Murung Raya district is the Kedemangan Institution. According to Keretangan Damang, Murung Raya Regency Coordinator, that origin start off the region Royalty that existed at that time was the region Top of the Cascade and the Bottom of the Cascade. Since the change in the period of regional autonomy with the division of Baru Regency from North Barito Regency as the parent district, the region's recognition palisade undergo an adjustment determined by a Decree of the Regent of Murung Raya that is to become 5 Regions Royalty among others: Royalty Depressed, Royalty East Afternoon, South Afternoon Semematics, Lower Semam Semantic.

The purpose of empowering and preserving and developing the Customary Traditions, customs in the community, and Customary Institutions in the Regions is to support the smooth running of the Government, the continuation of development and improvement of national resilience, and to encourage efforts to the welfare of residents. The aim is to encourage, support, and increase community participation for smooth governance, implementation of development and community coaching in the regions, especially in villages so that local community members feel called to participate to be responsible for the welfare of people's lives and their environment. The structure of Kedemangan is determined in the Regency of Murung Raya, as follows;

1. The Regency Level is led by a Murung Raya or Tamanggung Demang Coordinator who is accompanied by the Murung Raya Regency Adat Council;

2. The Kecamatan level is led by a Customary Head Drought who is assisted by the Customary Assembly in the TerritoryRoyalty concerned; Among Other:
a. Damang Indigenous Head of Murung
b. Damang Kepala Adat Siang Selatan
c. Damang Kepala Adat Siang Timur
d. Damang Indigenous Head of Permata Intan
e. Damang Adat Head of Sumber Barito
f. Damang Indigenous Head of Uut Murung
g. Damang Head of the Thousand Riam Custom

3. The village level is led by a customary head who is assisted by customary mantir and community leaders according to needs. In the Regency Murung Raya, There are 115 villages and 11 villages.

Empowerment in the context of Dayak custom is inseparable from the role of the actor as a driving machine. Where actors have a very important role by using the "power" that is owned to build bonding, bridging, and networking. The actor in question is the Chairperson of Damang, Murung Raya Regency, WilsonTobing. For an explanation of the role of actors as the leading sector and local champion can be explained as follows:

\section{Bonding}

Based on the findings in the field, the role of actors as social glue remains an important point in the empowerment of Murung Raya Regency bonding in preserving the local wisdom of the Dayak Indigenous people. Where the bonding or binding or adhesives in the Dayak Traditional are members of a group that is homogeneous, kinship and the strongest glue is the actor (Mr. Wilson Tobing) a leader who is still a native son of Murung Raya Regency. Kinship within the Dayak Murung Raya Indigenous community gives rise to sympathy, empathy, a sense of belonging, mutual recognition of cultural values and creates rules for the community.

\section{Bridging}

One of the strengths of Empowerment owned by the Dayak Indigenous Murung Raya Regency is the ability to communicate and connect relationships in the Regency both individually and in groups that support the preservation of local wisdom Dayak Siang Murung Raya. In the context of Dayak Adat, a bridging process has been carried out between the activities carried out by the Dayak Adat community and the local government, which until now has been well established. This is also inseparable from the role of the actor, where the position as Regional Head and Chair of Damang makes the bridging process easier and can be well organized. This bridging process can be seen from 
the activities that have been carried out by Adat Dayak Murung Raya. Every activity can run well and continue.

a. Following the Ngocing Dance Festival which has been held annually, in various events since 2016. Ngocing dance taken from the Dayak Siang language is one of the dances of the almost extinct Dayak Murung Raya community. Therefore, Dayak Customs collaborates with the Regional Government and indigenous people to take part in this festival.

b. Settlement of customary land disputes. Both conflicts between individuals and between indigenous peoples and companies.

c. Granting custom title. The award was given to figures who were considered to have contributed to the development of culture and development in Murung Raya Regency.

\section{Linking}

Linking empowerment shows a potential form of community power. This potential is very much determined by the beliefs and norms owned by the community. Where the core of Empowerment strength lies in the high trust owned and obedience to norms by members in the community. The power of empowering connections, networks (linking social capital), is almost the same bridging social capital the orientation is external where it is effective in building relationships and networks in groups with different social strata [11].

Based on the reality found in the field, the linking happened in the Dayak Indigenous community of Murung Raya Regency. Relations network that is formed not only in social groups with different social strata but also Dayak Customs also forms a network of relations with the same social strata [12]. This phenomenon can occur due to the tomemberIndigenous Dayak community of Murung Raya Regency is a member who has a position as a regional government and as a businessman. The Dayak Indigenous Members of Murung Raya Regency are important stakeholders so that when building linking or cooperation it tends to be easier and can be well organized. In the context of empowering linking, Dayak adat members as actors are important indicators owned by the community as a form of Dayak adat empowerment power. Factors affecting the implementation of policy refer to the George C. Edward III model, as follows;

\section{Resources}

According to Edward III, resources are important in implementing good policies [13]. An institutional Dayak custom that has been preserved since the beginning is Damang in an area. Damang is the central institution that is expected to provide servicesPublicaccording to their respective interests. Several things become influential resources of this policy, such as; 1) Human Resources in the form of Damang Adat Chief and Mantir, 2) RegionsRoyalty which can cover One District area, 3) Resources of existing and preserved customary rights, in the form of sites, forests, and land.

\section{Communication}

The communication factor is very influential on the acceptance of the policy by the target group so that the quality of communication will influence in achieving the effectiveness of public policy implementation. Thus, the dissemination of policy content through a good communication process will affect the implementation of the policy. In this case, the communication media used to disseminate the contents of the policy to the target group will play an important role.

Communication is one of the important variables that influence the implementation of public policies, communication is crucial to the success of achieving the objectives of public policy implementation [14]. Effective implementation will be carried out if the decision-makers know about what they will do. Information that is known to decision-makers can only be obtained through good communication. Three indicators can be used to measure the success of the communication variable. Edward III put forward these three variables, namely:

1. Transmission. Good communication will be able to produce a good implementation (based on Regional Regulation 16/2008 applied to Central Kalimantan). In the formation, policy Institutional Dayak traditions in Central Kalimantan have been carried out several forms of Communication Forum in Institutional development in the form of Regional Deliberation of Dayak Murung Raya Adat Council as many as have been carried out until MUSDA II in 2017.

2. Clarity, communication received by policy implementers (street-level-bureaucrats) must be carried out clear and not confusing or ambiguous. In this Institutional Formation Policy, it was found to be unclear that the Regional Regulation 16 of 2008 was in effect in Central Kalimantan, Murung Raya Regency did not make Adjustments to the old Regional Regulation 5/2006 in the districtGunung Masenacted Perda 33 of 2011 concerning Dayak adat institutions in Gunung Mas district.

3. Consistency, orders given in the implementation of communication must be consistent and clear to be established or carried out. The Consistency Policy of the Formation of Customary Institutions has Changed to Adjustment of Incentives for Damang and Damang tenure $[14,13]$. 


\section{CONCLUSION}

The purpose of the Formation and Empowerment of Dayak Indigenous Institutions in Murung Raya Regency is to support the smooth running of the Government, the continuation of development, and the improvement of national resilience. Besides, encouraging efforts to improve the welfare of residents and encourage, support, and increase community participation for the smooth running of government, implementation of development, and community development in the regions, especially in rural/urban villages. The Kademangan structure is established in Murung Raya district, the Regency Level is led by a Demang Coordinator, the District Level is led by a Customary Head Drought, the Village level is led by a Customary Head.

Position of Customary Institutional Duties and Functions in Murung Raya Regency, Demat Coordinator of Local Government partners in the field of preservation, empowerment, and custom development. Customs of the community and customary institutions and customary law in the area. Demang Adat is a Camat partner in the field of preservation, empowerment, and development of customs, customs, and practices of the community and customary institutions in the region. Customary Head is the partner of the Village / Lurah Head in the field of preservation, empowerment, development of customs, habits of the community and customary institutions and customary law in the area. Factors affecting the Implementation of Institutional Formation and Empowerment of Dayak Indigenous Peoples in the District of Murung, include:

1. Damang is the center of an institution that is expected to provide services Public according to their interests.

2. Resource Humans in the form of Customary Damang along with Regional Mantir Royalty which can cover One District area.

3. Existing and preserved rights of customary rights in the form of sites, forests, and land.
4. Damang and Mantir cause enthusiasm in carrying out the Task. So deep development the absence of a Perda on the recognition and protection of the Murung Raya Indigenous Peoples influences the Service Standards at the Dayak Indigenous Institutions.

\section{REFERENCES}

1. Islamy, I. (2000). Prinsip-prinsip Perumusan Kebijaksanaan Negara. Jakarta: Penerbit Bumi Aksara.

2. Wibawa, S. (1994). Evaluasi Kebijakan Publik. Jakarta: Raja Grafindo.

3. Winarno, B. (2002). Teori dan Proses Kebijakan Publik. Yogyakarta: Media Pressindo.

4. Purwanto, D. (2012). Implementasi Kebijakan Publik Konsep dan Aplikasinya. Yogyakarta: Gava Media.

5. Parsons, W. (2001). Pengantar Teori dan Praktik Analisis Kebijakan (Terj. Tri Wibowo Budi Santoso). Jakarta: Kencana.

6. Tachjan. (2006). Implementasi Kebijakan Publik. Bandung: AIPI Puslit KP2W Lemlit Unpad.

7. Taylor, S. J., \& Bogdan, R. (1993). Promises made and promises to be broken. The ADA mandate for social change, 255-268.

8. Gunawan, I. (2014). Metode Penelitian Kualitatif Teori dan Praktik. Jakarta: Bumi Aksara.

9. Saebani, A. D. (2009). Metodologi Penelitian Kualitatif. Pustaka Setia: Bandung.

10. Sugiyono. (2008). Memahami Penelitian Kualitatif. Bandung: Penerbit Alfabeta.

11. Wahab, S. A. (2001). Analisis Kebijaksanaan, dari Formulasi ke Implementasi Kebijaksanaan Negara, Edisi Kedua. Jakarta: Bumi Aksara.

12. Budiman, N. (1996). Pengantar Kebijakan Publik. Jakarta: PT. Raja Grafindo Persada.

13. Agustino, L. (2006). Politik dan Kebijakan publik. Bandung: AIPI.

14. Edward III, G. C. (1980). Implementing Public Policy. Washington DC:: Congressional Quarterly Press. 